\title{
Discussion: Settlement of floor slabs on stone columns in very soft clays
}

Richard S. Pugh PhD, MSC, BSC, CEng, FICE Director, Richard Pugh Consulting, Cranbrook, UK
Colin J. Serridge BSC (Hons), MSc, PhD, CGeol, FGS, EurGeol Chief Engineer, Balfour Beatty Ground Engineering, Manchester, UK

\section{Contribution by C. J. Serridge}

Pugh (2017) presented an interesting paper on the settlement of floor slabs on stone columns in very soft clays, including useful commentary on limitations, with reference to two case histories of poor performance (serviceability failures) where inappropriate methods of procurement of the stone column option were highlighted as having led to inadequate geotechnical engineering input to the design and a failure to provide the specialist contractor with sufficient information for the design. This is welcomed as, firstly, there is a lack of such case history information available in the literature (as evident from Table 1 in the paper, where the case history information cited is relatively historic and also principally relating to embankments) and, secondly, it highlights the difficulties/ challenges that a specialist contractor is faced with when assessing the suitability of stone columns in very soft clays, in particular for ground-bearing floor slab support.

The important distinction is made by the author between stone column applications in very soft clays beneath embankments (where the principal load is from the dead load of the embankment construction and with the majority of the primary consolidation taking place during the construction phase) and beneath ground-bearing floor slabs, where the principal load contribution is typically from the live load, which is not realised until after completion of the structural slab installation.

Stone columns have been used successfully in the UK over the last 50 years in a range of ground conditions and in a range of applications for lightweight low-rise structures (including ground-bearing floor slabs), earthworks embankment support, retaining structures, tanks, and for stability control - and indeed continue to be so used. However, when much is demanded of stone columns the benefits will inevitably be less and it is generally recognised that they have limitations in very soft clays beneath ground-bearing floor slabs in terms of achieving normal serviceability criteria, particularly when factoring in secondary consolidation creep effects.

Based upon the contributor's experience with soft to very soft clay soils, the practical upper-bound percentage soil replacement achievable with stone columns is of the order of $15 \%$ in widespread floor slab applications in order to mitigate excessive soil disturbance or ground heave when using the dry bottom-feed (displacement) technique (which has largely replaced the wet top-feed (vibro-replacement) technique on environmental grounds within the UK, with perhaps a few exceptions in coastal reclamation projects for example). This typically limits reduction of primary consolidation settlements to around $40-50 \%$ in soft to very soft clay soils beneath floor slabs, dependent upon how live loads are applied/distributed. Serridge (2015) provides some guidance on best-practice stone column construction in soft fine-grained soils using the dry bottom-feed method. It is noted that the author's suggested design curve (Figure 7(b) in the original paper) for widespread loading on very soft clays, based upon the case history information reviewed, suggests a peak settlement reduction of $40 \%$ at $20 \%$ stone replacement.

It is not unusual for stone columns to be sought as an alternative to piling for ground-bearing floor slab support in very soft clays, and for this to take place at a late stage in the procurement process, with the specialist contractor often having to rely upon ground investigation information originally targeted at a piling solution, often with inadequate geotechnical characterisation of the shallower very soft to soft soil deposits, through which stone columns are required to be installed and also work in combination with. Where one has to rely solely upon interpreting soil undrained shear strength and compressibility indirectly from SPT $N$ values, this can lead to the use of coefficient of volume compressibility $\left(m_{\mathrm{V}}\right)$ values, for example, which are an order of magnitude out, leading to underprediction of pre-treatment settlements. Thus, if there is sufficient geotechnical information to reliably predict the likely magnitude of the primary and secondary consolidation settlements without stone columns, the risks of not achieving the required serviceability limits for the slab, provided the dead and live loads have been accurately specified, can be established, in theory, relatively easily when assessing the feasibility of stone columns.

Therefore, in order to permit better risk assessment/ management of the application (or otherwise) of stone columns beneath floor slabs in very soft clays, the procurement process - including the type and quality of site and ground investigation information - does need to be improved, as alluded to by the author, so that both primary and secondary consolidation (creep) settlement implications can be assessed, together with a clear specification of loadings and required total and differential settlement criteria. The duty of care of the specialist contractor in understanding the deficiencies in the ground and providing the correct advice and implementing the appropriate equipment, expertise and quality control, 
commensurate with the geotechnical complexity of the ground, is equally important.

Some ways in which risk can be more effectively managed during the procurement process are summarised as follows.

Ensuring any deficiency in the ground has been correctly diagnosed and, by inference, that the soil profile has been satisfactorily characterised geotechnically using in situ testing (e.g. CPT piezocone, field vane testing), 'undisturbed' sampling and subsequent laboratory testing methods commensurate with the sensitive, easily disturbed nature of soft to very soft compressible clay soils.

- Providing specialist contractors with site investigation information that should include an appropriate desk study (with previous site history) and a factual report section, rather than just a suite of borehole logs, which can often be the case. Eurocode 7 (CEN, 2004) is clear on what is required.

- Providing clear specification of the live and dead loadings for the floor slab (and construction), including details of how the live loads are likely to be applied/distributed and any point loads from mezzanines, racking or wheels. Modulus of sub-grade reaction or CBR values are sometimes specified, which, while assisting the floor slab design, are not directly appropriate for the performance of very soft clays reinforced with stone columns.

- Ensuring that total and differential settlement requirements have been clearly specified.

- Engaging at an early stage with specialist ground improvement contractors to assess the feasibility of stone columns, accept advice on any deficiencies in the site investigation information and obtain agreement from all parties regarding the benefits of expending additional monies on additional ground investigation compared with the costs of remedials at a future date if the ground risks are not effectively managed.

- Where stone columns are being considered for ground floor support in soft clays (as an alternative to piles) and where main foundations are supported on piles, ensuring that adequate provision been made in the structural design to accommodate differences in settlement performance associated with the two systems. This might include, for example, the provision for a granular cushion or proprietary compressible material between the underside of the slab and the top of the pile caps.

- Obtaining greater involvement of geotechnical consultants in the reviewing/vetting of stone column proposals during the procurement process before the award of vibro-ground improvement subcontracts.

- Ensuring that the structural design of the slab reflects a stone column option, recognising that load share between stone columns and the intervening soil is complex with less chance for a full equilibrium condition to be achieved during construction under floor slabs compared with embankments.

There is a need for greater research into the performance of stone columns for ground-bearing floor slab support in soft and very soft clays, including partially penetrating stone columns in deep soft clay deposits, the influence of stone columns on the magnitude of secondary consolidation creep and also the beneficial effects of surface crusts in normally to lightly over-consolidated clay profiles.

Over recent years there has been an increase in the application of rigid inclusion ground improvement systems (used in conjunction with a granular load transfer mattress, with or without geogrid, dependent upon rigid inclusion type and application), in very soft clays beneath ground-bearing floor slabs, reducing some of the risks associated with stone columns, without recourse having to be made to a fully piled suspended floor slab arrangement.

\section{Authors' reply}

The author thanks the discusser for this valuable contribution with respect to soil disturbance during stone column installation. The discusser's stated experience is that, for stone columns to support widespread loading on very soft clays, the practical upper-bound stone replacement to mitigate against excessive installation-induced soil disturbance is of the order of $15 \%$, with the corresponding practical upper-bound settlement reduction being of the order of $40-50 \%$. The discusser's experience corroborates the conclusions drawn in the paper (Figure 7) in respect of both decreasing stress concentration ratios and stone column efficiencies with increasing stone replacement and little benefit being provided by increasing stone replacement much beyond $15 \%$.

As noted in the paper, the two serviceability case histories indicated primary settlement reduction corresponding to Priebe (1995). It was postulated that this was the result of relatively little soil disturbance (yielding and excess pore pressures) during column installation as a consequence of low stone replacements and correspondingly high column spacing/ diameter ratios (Table 3), these also suggesting that the columns did not act as groups (Bergado and Lam, 1987; Hughes and Withers, 1974).

In both case histories installation was by the dry bottom-feed method and while in one case workmanship was good, in the other it was certainly not. Thus, while the discusser quite rightly refers to the need for best practice to minimise soil disturbance during column installation in very soft clays the - albeit anecdotal - evidence of the case histories suggests that, in practice, the column spacing/diameter ratio exerts a greater influence on soil disturbance and stone column efficiency than workmanship. 
The discusser also provides useful guidance on the measures required to effectively manage the procurement of stone columns to support floor slabs on very soft clays and the risks associated with their use in these circumstances. However, based on experience, the author is sceptical as to whether the discusser's eminently reasonable requirements, which would certainly be met for major civil engineering works, are likely to be achieved under the form of design and build contracts and specialist subcontracts currently used by the building industry. Within this contractual arrangement, the decision on stone column viability is inevitably taken by the specialist contractor, either in response to preliminary enquiries from the project team or, more often than not, simply by submitting a design and build tender to the main contractor.

The stone column design is performed by the specialist contractor and provided as part of their tender to the main contractor. Designs are generally based on elastic settlement analyses and Priebe (1995) settlement reduction factors with geotechnical input limited to selection of soil compressibility parameters from limited geotechnical data. The successful tenderer is likely to be the one that contracts to provide the required settlement reduction for the least stone replacement. Under the current Eurocode 7 (CEN, 2004), the specialist contractor becomes the de facto geotechnical engineer and is responsible for the project geotechnical design report within the constraints of a design and build subcontract that provides neither the means to properly execute the role nor to manage the risks, which of course ultimately lie with the specialist contractor.

\section{REFERENCES}

Bergado DT and Lam FL (1987) Full scale load test of granular piles with different proportions of gravel and sand on soft Bangkok Clay. Soils and Foundations 27(1): 86-93.

CEN (European Committee for Standardization) (2004) EN 1997-1: Eurocode 7: Geotechnical design - part 1: general rules. CEN, Brussels, Belgium.

Hughes JMO and Withers NJ (1974) Reinforcing of soft soils with stone columns. Ground Engineering 7(3): 42-49.

Priebe HJ (1995) The design of vibro replacement. Ground Engineering 28(10): $31-37$.

Pugh R (2017) Settlement of floor slabs on stone columns in very soft clays. Proceedings of the Institution of Civil

Engineers - Geotechnical Engineering 170(1): 16-26, http://dx.doi.org/10.1680/jgeen.15.00150.

Serridge CJ (2015) Briefing: Dry bottom-feed stone column construction in soft fine-grained soils. Proceedings of the Institution of Civil Engineers - Ground Improvement 168(3): 159-161, http://dx.doi.org/10.1680/grim.14.00019. 